\title{
TRENDS IN RESEARCH ON THE POSSIBLE EFFECTS OF CLIMATE CHANGE CONCERNING AQUATIC ECOSYSTEMS WITH SPECIAL EMPHASIS ON THE MODELLING APPROACH
}

\author{
CS. SIPKAY ${ }^{1}-$ K.T. KISS ${ }^{2}-$ CS. VADADI-FÜLÖP ${ }^{3}-$ L. HUFNAGEL ${ }^{4} *$ \\ ${ }^{1}$ Department of Mathematics and informatics, Corvinus University os Budapest, \\ H-1118 Budapest, Villányi út 29-33, Hungary \\ (+36-1-372-6261; fax: +36-1-466-9273) \\ ${ }^{2}$ Hungarian Danube Research Station, Hungarian Acaemy of Sciences, \\ H-2131 Göd, Jávorka Sándor u. 14. Hungary \\ ${ }^{3}$ Department of Systematic Zoology andEcology, Eötvös Loránd University, \\ H-1117 Budapest, Pázmány Péter sétány 1/c, Hungary \\ ${ }^{4}$ „Adaptation to Climate Change” Research Group of Hungarian Academy of Sciences \\ H-1118 Budapest, Villányi út 29-33, Hungary \\ (phone: +36-1-482-6261; fax: +36-1-466-9273) \\ *Corresponding author \\ e-mail: leventehufnagel@gmail.com \\ (Received $2^{\text {nd }}$ February 2009; accepted $6^{\text {th }}$ July 2009)
}

\begin{abstract}
Knowledge on the expected effects of climate change on aquatic ecosystems is defined by three ways. On the one hand, long-term observation in the field serves as a basis for the possible changes; on the other hand, the experimental approach may bring valuable pieces of information to the research field. The expected effects of climate change cannot be studied by empirical approach; rather mathematical models are useful tools for this purpose. Within this study, the main findings of field observations and their implications for future were summarized; moreover, the modelling approaches were discussed in a more detailed way. Some models try to describe the variation of physical parameters in a given aquatic habitat, thus our knowledge on their biota is confined to the findings based on our present observations. Others are destined for answering special issues related to the given water body. Complex ecosystem models are the keys of our better understanding of the possible effects of climate change. Basically, these models were not created for testing the influence of global warming, rather focused on the description of a complex system (e. g. a lake) involving environmental variables, nutrients. However, such models are capable of studying climatic changes as well by taking into consideration a large set of environmental variables. Mostly, the outputs are consistent with the assumptions based on the findings in the field. Since synthetized models are rather difficult to handle and require quite large series of data, the authors proposed a more simple modelling approach, which is capable of examining the effects of global warming. This approach includes weather dependent simulation modelling of the seasonal dynamics of aquatic organisms within a simplified framework.
\end{abstract}

Keywords: ecological modelling, model system, community ecology, global warming, seasonal dynamics

\section{Introduction}

On the basis of scientific knowledge and observations, it can be stated that global warming has become a reality in the $20^{\text {th }}$ century, which has an anthroponetic origin. Since 1850, global mean temperatures have increased by $0.76^{\circ} \mathrm{C}$. Between the years of 1995 and 2006 (12 years), 11 years ranged within the warmest ones measured since 1850. In order to determine the effects of climate change expected, the emissions data of social-economic developmental stages are used. Results indicated at least $2{ }^{\circ} \mathrm{C}$ 
increase in temperature in the $21^{\text {st }}$ century, however it can be $5^{\circ} \mathrm{C}$ as well (IPCC 2007 , a).

Climate change can influence aquatic ecosystems in a very sensitive way. Arid periods can bring marshland into shrivelling, increasing evaporation reduce water surface in ponds and may bring in a low water stage for a good while (Hufnagel et al. $2008)$. In the latest IPCC report $(2007, b)$, there was evidence of earlier deductions, namely increasing water temperature has a negative effect on the water quality of lakes by reducing the oxygen concentration in the hypolimnion, releasing of phosphorus from the sediment and changing the mixing patterns (McKee et al. 2003; Verburg et al. 2003; Winder \& Schindler 2004, Jankowski et al. 2006). Beyond the large scale processes and habitat changes mentioned above, there are many other effects of drastic warming which cannot be explored without deeper understanding of the relationship between aquatic communities and weather conditions (especially temperature).

Essentially, seasonal dynamics is determined by the climate, principally by temperature. The concept of seasonal dynamics has been published in several forms. It has been come out like "seasonal variation”, seasonal changes" or "seasonal cycle” considering changes in the abundance, biomass or in the composition of assemblage. Generally, seasonal dynamics is the temporal change (individual numbers and composition) of the examined assemblage. Since these processes are influenced by climate (principally temperature), collecting data on seasonal dynamics and exploring its connections with weather conditions (mainly temperature) and also modelling may result in deeper understanding of the effects of climate change.

Our knowledge on the seasonal succession of freshwater (mostly lake) systems is not so deep than those of terrestric systems. In addition, in aquatic habitats researchers did not identify such distinct successional states than in terrestric food webs. It is not meaningful to look at the pelagic zone of lake systems as one food web, rather succession of different food webs. Take the so-called PEG (Plankton Ecology Group) model (Sommer et al. 1986) adapted to describe the seasonal succession of freshwater plankton. It distinguishes 24 successional states with different significance of abiotic factors and biotic interactions. This plankton succession model is the first one among models constructed on the basis of synthetizing numerous case studies in that topic; however, it is valid only for temperate deep lakes of definite stratification. There are no more general succession models available for other types of water bodies such as shallow lakes.

Still our knowledge on seasonal succession in aquatic ecosystems has some shortcomings due to the small size of planktonic elements playing a major role in this process. However, plankton communities are in the focus of such research owing to their small size and high reproduction rate, thus they respond to indirect effects within a short period as well (Straile 2005). To illustrate this point take e. g. the r-strategic centric diatoms (Centrales) in the River Danube, which are able to proliferate within a day resulting in rapid multiplication, thus, high regeneration of phytoplankton after flood events (Kiss 1986).

Since the phytoplankton plays a crucial role in climate control, investigations of such communities are of major importance in relation to global warming (Charlson et al. 1987; Williamson \& Gribbin 1991). Due to the high biomass and photosynthetic activity, phytoplankton generates half of the oxygen quantity needed for human life; moreover by fixing carbon-dioxide it has a major contribution to climate control (Duinker \& Wefer 1994). 
There are some more reasons supporting the significance of such plankton surveys. Since the last glacial maximum, variation in environmental variables based on the variation of planktonic communities in lake systems within a year seems to be analogous with climate change in the past (Reynolds 1997). There is strong evidence for systematic changes in plankton abundance and community structure over recent decades in many areas worldwide. Ongoing plankton monitoring programmes worldwide (some have now been running for more than 50 years, e. g. CalCOFI in California, Odate in Japan, Continuous Plankton Recorder in the North Atlantic) will act as sentinels to identify future changes in marine ecosystems (Hays et al. 2005). It has been shown that abundance and structure of the zooplankton community display considerable variations on seasonal, interannual, and regional scales (Arashkevich et al. 2002). Predictable patterns of biodiversity often occur in freshwater pelagic communities over yearly cycles in temperate regions of the globe (Bernot et al. 2004).

Several studies draw attention to the negative effects of climate change on fish (Rahel et al. 1996; Schindler 1997; Stefan et al. 2001). Many studies are run on the mostly harmful - consequences of climate change on the water quality of freshwater ecosystems, habitat of fish, fish communities and fishery exploitation. In the recent past, a review was published on this topic (Ficke et al. 2007).

There have been some articles summarizing our knowledge on the possible effects of climate change on aquatic habitats in general (Carpenther et al. 1992, Schindler 1997). The Pew Center (Poff et al. 2002) has summarized such results for the U.S. by presenting several case studies for all types of freshwater and marine ecosystems. Most reviews - significant in the sense of community ecology as well - discuss limnobiological aspects. Straile (2005) gives a detailed overview of our recent knowledge on the effects of climatic factors on the food web and seasonal dynamics of lakes in the temperate zone, discussing also the possible effects of climate change primarily focusing on plankton communities.

According to the database of Web of Science, there was a total of 45209 articles published dealing with climate change until February 2009, from which $3.7 \%$ concerns biodiversity and/or ecology (Table 1.). In a wider sense, $8.6 \%$ of articles discuss ecosystem-related questions. Despite the large proportion of water bodies $(24.6 \%)$ including lakes $(6.9 \%)$ and rivers $(7.6 \%)$, studies on their ecosystems add up to $0.6 \%$ only. When focusing on articles having relevancy in community ecology (which add up to $0.6 \%$ only without closer restrictions), there are few of them concerning freshwater systems. This indicates that there is a need for putting emphasis on the research of climate change in relation to community ecology in water systems as well.

From the point of view of exploitation, research on fish has been a thoroughly investigated field among hydrobiological surveys, also in relation to climate change. Beyond doubt, the significance of phytoplankton in climate change research is of major importance, which is confirmed by the large number of publications. However, freshwater habitats are underrepresented, what is more, lakes are favoured over rivers. Nevertheless, more studies are run on the relationship between rivers and climate change as compared to that of lakes. Such features can be seen in modelling studies as well. Among climate change research, the modelling approach has been strongly adopted even by aquatic surveys. Rivers have been the objects of modelling more regularly than lakes, which is in accordance with the fact, that rivers are expected to respond to climate change in a very sensitive way. However, phytoplankton modelling studies have rarely focused on rivers. All in all, these findings draw attention to the 
significance of rivers as far as climate change is concerned; however, their ecological features remained relatively poorly-known.

Table 1. Number of publications dealing with climate change and their proportion in \% based on different combinations of key words in the database of Web of Science

\begin{tabular}{l|c|c}
\hline Keywords & pc & \% \\
\hline Climate change & 45209 & $100,0 \%$ \\
Climate change AND biodiversity & 1654 & $3,7 \%$ \\
Climate change AND ecology & 1654 & $3,7 \%$ \\
Climate change AND ecosystem & 3878 & $8,6 \%$ \\
\hline Climate change AND water & 11104 & $24,6 \%$ \\
Climate change AND lake & 3112 & $6,9 \%$ \\
Climate change AND ocean & 5897 & $13,0 \%$ \\
Climate change AND river & 3421 & $7,6 \%$ \\
\hline Climate change AND lake ecosystem & 267 & $0,6 \%$ \\
Climate change AND river ecosystem & 254 & $0,6 \%$ \\
Climate change AND aquatic ecosystem & 155 & $0,3 \%$ \\
Climate change AND wetland 495 & 495 & $1,1 \%$ \\
\hline Climate change AND ecology AND community & 290 & $0,6 \%$ \\
Climate change AND aquatic community & 89 & $0,2 \%$ \\
Climate change AND aquatic food web & 31 & $0,1 \%$ \\
\hline Climate change AND lake AND arctic & 286 & $0,6 \%$ \\
Climate change AND lake AND subarctic & 46 & $0,1 \%$ \\
Climate change AND lake AND temperate & 176 & $0,4 \%$ \\
Climate change AND lake AND tropic & 2 & $0,0 \%$ \\
\hline Climate change AND zooplankton & 330 & $0,7 \%$ \\
Climate change AND phytoplankton & 704 & $1,6 \%$ \\
Climate change AND phytoplankton AND lake & 188 & $0,4 \%$ \\
Climate change AND phytoplankton AND river & 67 & $0,1 \%$ \\
\hline Climate change AND fish & 898 & $2,0 \%$ \\
Climate change AND fish AND lake & 157 & $0,3 \%$ \\
Climate change AND fish AND river & 148 & $0,3 \%$ \\
\hline Climate change AND model & 13964 & $30,9 \%$ \\
Climate change AND model AND water & 6281 & $9,5 \%$ \\
Climate change AND model AND lake & 137 & $1,4 \%$ \\
Climate change AND model AND river & 297 & $0,4 \%$ \\
\hline Climate change AND phytoplankton AND model & $0,3 \%$ \\
\hline & &
\end{tabular}


On the basis of the reviews the possible effects of climate change have been investigated by four approaches:

- One possible tool is based on long-term field monitoring and observation of climatic events in the last decades; it describes the tendency attributable to climate change in aquatic ecosystems. Such findings are the basis for making predictions to the possible future changes. In the future, a more drastic climate change is expected as compared to the recent past, which may bring more significant effects and may create several unexpected processes.

- Other works forecast possible future scenarios by examining the connections between paleolimnological fossils and climate change in the past (Quinlan et al. 2005, Larocque et al. 2001). Research on lake sediments is particularly capable of supporting evidence for the effects of climate change on lake systems in the past (Cohen, 2003). Nevertheless, such findings are limited and it is questionable whether they are capable of understanding the relationship between certain coenological processes and climate change. On the other hand, future climate change affects waters harmed by human activity, thus the outcome may be somewhat different than in the past.

- One more approach includes microcosm (e. g. McKee et al. 2002, Peperzak 2003) and mesocosm (e. g. Nouguier et al. 2007, Christoffersen et al. 2006, McKee \& Atkinson 2000) experiments, which are able to simulate the global warming within a long-term experiment under laboratory or at least regulated conditions. Thus, within an experimental design, it is possible to study the reaction of the assemblage on warming. Present approach is particularly suitable for the interpretation of certain phenomena and for hypothesis testing. On the basis of the experiments there is a potential to form new hypotheses and set up mathematical models (e. g. De Senerpont Domis et al. 2007).

- Finally, the modelling approach is a useful tool to make predictions for the future (as long as the assumptions are fulfilled), that we cannot achieve either by means of simulation experiments or field work.

The topic is rather diversified, so it would mean an enormous effort to review all stream thoroughly. It is inevitable to have a look at the observations on the climate change in the recent past and these days, thus we can make predictions of the possible effects and trends of climate change in the future. However, present study is not destined for detailed description of issues such as paleoecological research and experimental approach, because these topics have grounds of their own. Research on the possible effects of climate change is typically the topic that cannot be investigated by empirical approach; even experiments may result in formulating new hypotheses or focusing on minor issues only. Thus, here, the modelling approach will be discussed in a more detailed way.

\section{Observed effects of climate change and implications for the future}

\section{General statements for temperate freshwater systems}

Rising water temperatures induce direct physiological effects on aquatic organisms through their physiological tolerance. This, mostly species-specific effect can be demonstrated through the examples of two fish species, the eurythermal carp (Cyprinus carpio) and the stenothermal Salvenius alpinus (Ficke et al. 2007). Physiological 
processes, such as growth, reproduction and activity of fish are affected by temperature directly (Schmidt-Nielsen 1990). Species may react on changed environmental conditions by migration or acclimatization. Endemic species, species of fragmented habitats, and systems with east-west orientation are less able to follow the drastic habitat changes due to global warming (Ficke et al. 2007). At the same time, invasive species may spread, which are rather able to tolerate the changed hydrological conditions (Baltz \& Moyle 1993).

What is more, global warming induces further changes in physical and chemical characteristics of water bodies. Such indirect effects include decrease in dissolved oxygen content (DO), change in toxicity (mostly increasing levels), trophic status (mostly indicating eutrophication) and thermal stratification.

DO content is related to water temperature. Oxygen gets into water through diffusion (e. g. stirring up mechanism by wind) and photosynthesis. Plant, animal and microbial respiration decrease the content of DO, particularly at night when photosynthesis based oxygen production does not work. When oxygen concentration decreases below 2-3 $\mathrm{mg} / \mathrm{l}$ we have to face the hypoxia. There is an inverse relationship between water temperature and oxygen solubility. Increasing temperatures induce decreasing content of DO whereas the biological oxygen demand (BOD) increases (Kalff 2000), thus posing a double negative effect on aquatic organisms in most systems. In the side arms of eutrophic rivers, the natural process of phytoplankton production-decomposition has an unfavourable effect as well. Case studies of the side arms in the area of Szigetköz and Gemenc also draw attention to this phenomenon: high biomass of phytoplankton caused oxygen depletion in the deeper layers and oversaturation in the surface (Kiss et al. 2007).

Several experiments were run on the effects of temperature on toxicity. In general, temperature dependent toxicity decreases in time (Nussey et al. 1996). On the other hand, toxicity of pollutants increases with rising temperatures (Murty 1986.b), moreover there is a positive correlation between rising temperatures and the rate at which toxic pollutants are taken up (Murty 1986.a). Metabolism of poikilotherm organisms such as fish increases with increasing temperatures, which enhances the disposal of toxic elements indirectly (MacLeod \& Pessah 1993). Nevertheless, the accumulation of toxic elements is enhanced in aquatic organisms with rising temperatures (Köck et al. 1996). All things considered, rising temperatures cause increasing toxicity of pollutants.

Particularly in lentic waters, global warming has an essential effect on trophic state and primary production of inland waters through increasing the water temperature and changing the stratification patterns (Lofgren 2002). Bacterial metabolism, rate of nutrient cycle and increase in algal abundance are increasing with rising temperatures (Klapper 1991). Generally, climate change related to pollution of human origin enhances eutrophication processes (Klapper 1991; Adrian et al. 1995). On the other hand, there is a reverse effect of climate change inasmuch as enhancement of stratification (in time as well) may result in concentration of nutrients into the hypolimnion, where they are no longer available for primary production (Magnuson 2002). The latter phenomenon is only valid for deep, stratified lakes with distinct layers of aphotic and tropholitic.

According to the predictions of global circulation models climate change is more than rise in temperatures purely. The seasonal patterns of precipitation and related flooding will also change. Frequency of extreme weather conditions may intensify in water systems as well (Magnuson 2002). Populations of aquatic organisms are 
susceptible to the frequency, duration and timing of extreme precipitation events including also extreme dry or wet episodes. Drought and elongation of arid periods may cause changes in species composition and harm several populations (Matthews \& Marsh-Matthews 2003). Seasonal changes in melting of the snow influence the physical behaviour of rivers resulting in changed reproduction periods of several aquatic organisms (Poff et al. 2002). Due to melting of ice rising sea levels may affect communities of river estuaries in a negative way causing increased erosion (Wood et al. 2002). What is more, sea-water flow into rivers may increase because of rising sea levels; also drought contributes to this process causing decreased current velocities in the river.

Climate change may enhance UV radiation. UV-B radiation can influence the survival of primary producers and biological availability of dissolved organic carbon (DOC). The interaction between acidification or pollution, UV-B penetration and eutrophication has been little studied and is expected to have significant impacts on lake systems (Magnuson 2002; Allan et al. 2002).

\section{Observed and expected reactions of aquatic communities}

Research on the relationship between climate change observed in the previous decades and aquatic food webs (Schindler et al. 1990, Livingstone 2003, Straile et al. 2003 ) is the key for getting a picture of the possible effects of global warming. There has been evidence for the effect of global warming on aquatic (particularly planktonic) communities in lakes, which was related to changes of some environmental parameters such as nutrient loading (Annaville et al. 2002; 2007; Molinero et al. 2006). The central regulatory role of climate in structuring the zooplankton community was demonstrated through the examples of European shallow lakes on the basis of surveys performed in 81 lakes (Gyllsrtröm et al. 2008). Pelagic plankton is the major dependent of climate change, benthic and periphytic taxa are rather influenced by macrophytes. Some studies put emphasis on specific aspects of climate change e. g. the duration of ice cover or the duration of spring full circulation (Rolinski et al. 2007), others stress the influence of temperature in a more general way (Wagner \& Benndorf 2006). Further characteristic trends in research of climate change in lakes are examination of the variation in duration of ice cover, spring phytoplankton blooms, clear water period, fish abundance and predator-prey interactions (Magnuson et al. 1990; Schindler et al. 1990; Scheffer et al. 2001; Winder \& Schindler 2004; Blenckner 2005; Mooij et al. 2005).

Climate change can affect aquatic food webs in many ways. It can alter duration and timing of the successional status (Straile 2002), or modify the structure of the food web within different successional stages (Wehenmeyer et al. 1999). In the life-history of certain species there may be some changes as well: timing of reproduction period of long-lived species or timing of metamorphosis by copepods, shifting of diapause towards earlier or later dates all may cause changes in the structure of the whole food web (Straile 2005).

Faster and more drastic warming of water bodies would result in earlier phytoplankton blooms implicitly. Several case studies forecast earlier peaks of algal biomass, which goes hand in hand with increased biomass (Flanagan et al. 2003), particularly in the winter term (Thackeray et al. 2008). Invasive cyanobacteria such as Cylindrospermopsis raciborskii playing a central role in blooms showed evidence for earlier population peaks (Wiedner et al. 2007). Peperzak (2003) found that four harmful algal species doubled their growth rates at a $4{ }^{\circ} \mathrm{C}$ temperature rise whereas two harmful 
species died rapidly within a microcosm experiment. Two non-harmful species did not significantly change from present to 2100-surface conditions. Christoffersen et al. (2006) conducted experiments in artificial ponds to evaluate the potential effects of global warming on picoplankton and nanoplankton populations. Their results demonstrated that the direct effects of warming were far less important than the nutrient effect, and these variables displayed complex interaction.

Lake food webs are characterized by professed seasonal dynamics, so the effect of climate is strongly dependent on season. Thus, we should not neglect the winter term often neglected due to the lower biological activity - to include in the study having particular importance in temperate lakes (global warming observed in the $20^{\text {th }}$ century is strongly manifested in the weather conditions of the winter term). In response to that the duration of ice cover period (Adrian et al. 1999, Weyhenmeyer 1999), and also timing and intensity of winter mixing caused by wind (Geadke et al. 1998), which has a significant effect on spring phytoplankton bloom formation, vary in lakes.

In the winter term, mixing period plays a crucial role in determining posterior peaks of phytoplankton production, thus investigation of that period has a major importance in climate change research. Mixing periods in sea and deep lakes are the analogies of barren land (Reynolds 1997). During the winter mixing period, primary production is limited by low temperatures, yearly minimum of incident radiation and yearly maximum of reflection from the water surface. As soon as these assumptions change during the year (increasing temperatures, increasing angle of incidence of solar radiation etc.) phytoplankton production begins to rise. Hence, the understanding and prediction the origin of phytoplankton blooms is of major importance, in this way we may get a picture of the possible outcomes of climate change and other environmental changes (Peeters et al. 2007). It has been shown in the side arms and dead arms of the River Danube that phytoplankton of high abundance can evolve in winter during ice cover dominated by species of cold-tolerant Centrales, Cryptophyta and Volvocales (Kiss \& Genkal 1993).

Shallow lakes are the objectives of such research more frequently since they are influenced by changing weather conditions more directly (Gerten \& Adrian 2001). Taking into consideration transparency as a fundamental factor in shallow lakes and accepting the concept of alternative stable state planes (Scheffer et al. 1993) the macrophytes dominated clear water state and the plankton dominated turbid state can be distinguished. When nutrient load rises towards critical levels there is a possibility for state change. However, phytoplankton dominated lakes can experience clear water state as well due to increased zooplankton grazing in spring mostly (Gulati et al. 1982; Sommer et al. 1986). Climate change is supposed to influence the transparency of shallow lakes in a negative way by destabilizing the macrophytes dominated clear water state and stabilizing the phytoplankton dominated turbid state (Mooij et al. 2005). This negative effect has been demonstrated through the examples of shallow lakes in the Netherlands and it is based on several findings. Increase in winter precipitation and extreme precipitation events increase the phosphorus load of lakes (Mooij et al. 2005). Rising temperatures cause inner nutrient increase (Jensen \& Andersen 1992; Liikanen et al. 2002). Rising temperatures increase mismatch of spring phytoplankton and zooplankton peaks owing to declined predation pressure of zooplankton. Moreover, high temperatures favour cyanobacteria meaning a less efficient nutrient for zooplankton (Dawidowicz et al. 1998; Gliwicz \& Lampert 1990). At the same time, predation pressure on zooplankton may increase because of decreasing winter mortality 
of fish (Mooij 1996; Mehner et al. 1995; Mooij \& Van Nes 1995; Nyberg et al. 2001). Increased rate of sediment resuspension is expected caused by wind (Schelske et al. 1995). Essentially the above-mentioned findings are based on case studies of shallow lakes in the Netherlands, however, Jeppensen et al. (2003) found similar characteristics in Danish shallow lakes implying that climate change creates eutrophication-like effects.

From the point of view of zones characterized by different fish assemblages in rivers, such as trout, grayling, barbel and bream zones, climate change seems to be a very interesting question. Characterization of rivers and river sections on the basis of such zones has been in the focus of interest for a long time (Fritsch 1872). First, Thienemann (1925) distinguished six zones, then, Huet (1949) tried to correlate them with abiotic factors such as water depth and decline of water. Temperature can be regarded as the major environmental parameter determining the development of fish assemblages and those zones along the river (Flebbe et al. 2006; Pont et al. 2006). Hence, rising water temperatures would result in realignment and shift of those zones. There have been some studies aimed at predicting the distribution of fish assemblages under rising temperatures by considering the biogeographical limiting factors at the present time (Eaton \& Scheller 1996; Rahel 2002).

However, a more drastic global warming is expected in the future, which has no signs in the climatic features of the last decades, generating changes in aquatic ecosystems. The significance of the topic is best highlighted by the study performed in Lake Tanganyika demonstrating that the negative effect of climate change can be more important than those of local human activity or overexploitation of fish stock (O'Reilly et al. 2003).

\section{Quantitative predictions for the future: possibilities for modelling}

Beyond doubt, the most plausible method for investigating the possible effects of climate change is the modelling approach. In these days, we are in possession of the global quantitative models of climate system (GCM), which - reflecting economic development and emission of pollutants both from optimistic and pessimistic points of view - are based on different emission scenarios. Models of global scale were downscaled for minor regions referred as regional circulation models (RCM). These models are capable of making quantitative predictions for the future climate on the basis of reconstruction of past climatic events relatively exactly. By means of the data series of regional climate models we are able to forecast possible future states of the populations of aquatic organisms. By describing physical changes of different aquatic habitats (e. g. change in temperatures, hydrological regime) hypotheses can be generated about the effects on the biota living in the water, and also we can make quantitative predictions by creating weather condition dependent models for the community or its elements. Nevertheless, in order to measure the possible effects of climate change on a complex aquatic ecosystem exactly, such model systems would be ideal keys that are capable of describing the relationship between communities and between communities and climatic factors quantitatively. However, such general ecosystem model systems are not typical, so we should make do with models of basic elements specified for a given habitat considering the boundary conditions as well.

Modelling of population dynamics of aquatic organisms has a long history. The German Victor Hensen leading the first great expedition on oceanography in 1889 
(Hensen 1892) introduced the terminus of plankton (based on the Greek expression of „planktos” $(\pi \lambda \alpha \gamma \kappa \tau \circ \varsigma)$ meaning ,wanderer” or „drifter”). It brought into a boom of research on fishing in the beginning of the $20^{\text {th }}$ century. At that time, the dynamics of fish stocks were described by means of mathematical models just as its connection with biological, physical factors and human impact (Cushing 1975; Gulland 1977; Steele 1977). At the same time, modelling of phytoplankton production began based on the studies of Fleming (1939), Ivlev (1945), Riley (1946) and Odum (1956) primarily. One characteristic trend in research included the control of algal blooms by zooplankton, which appeared first in the work of Fleming (1939) who described the temporal dynamics of phytoplankton biomass by the help of a differential equation. Modelling studies have used the Lotka (1925) and Volterra (1926) predator-prey interaction equations in numerous cases so as to describe the trophic connections between phytoand zooplankton (Segel \& Jackson 1972; Dubois 1975; Levin \& Segel 1975; Vinogradov \& Menshutkin 1977; Mimura \& Murray 1978).

Since the first half of the last century, several trends in modelling have evolved along diverse approaches and community ecological hypotheses often focusing on special issues such as understanding the background behind the dynamics of spatially inhomogeneous plankton communities on the basis of a model for predator-prey interaction including few species (Medvinsky et al. 2001).

In these days, two different modelling approaches seem to be relevant concerning aquatic systems (Peeters et al. 2007). One focuses on phytoplankton response on the grounds of minimalist models (Gragnani et al. 1999; Huisman et al. 2002; Huppert et al. 2002). This school focuses on special questions within the topic given. Such models are not in direct connection with field data, nevertheless, aimed at getting insight into essential ecological processes. The other one includes complex ecological models mostly aimed at modelling planktonic organisms and nutrients on the basis of field data taking into consideration physical, chemical and biological factors as well. Basically, these models aim at predicting long-term changes of the environment such as consequences of human impact and effects of climate change. Characteristically, they include a lot of terms meaning biotic components such as different groups of phytoplankton, zooplankton and higher trophic levels and also abiotic components i. e. environmental parameters measured in the field. In addition, they require very deep understanding of the investigated water body. The large number of parameters may cause several difficulties in complex ecological models (Omlin et al. 2001).

It is worthy to separate the models relevant from the point of view of climate change into two major groups:

- Some models use physics-based hydrological models or model systems often associated with chemical factors. Their common characteristics is that the focus is on modelling of the changes in the physical environment, and changes in community is explained through that (e. g. Hostetler \& Small 1999; Blenckner et al. 2002; Gooseff et al. 2005; Andersen et al. 2006).

- Another approach includes modelling of quantitative changes of a population or certain elements of a community in a given habitat. Mostly, phytoplankton is the objective of such studies often separated into some clusters e. g. green algae, diatoms, cyanobacteria (Mooij et al. 2007). On the basis of complexity and validity further subcategories can be generated:

- The first cluster includes simple models often related to a particular question which can be of major interest as well. Such models can also be 
relatively complex including several parameters, but the validity is confined to a close interval due to the special object of modelling or relation to a special environment (e. g. Matulla et al. 2007; Hartman et al. 2006; Peeters et al. 2007).

- Models can be combined into model systems or complex ecosystem models including several environmental factors such as nutrients and light, and it can also be combined with physical models (e. g. Elliott et al. 2005; Mooij et al. 2007; Komatsu et al. 2007; Malmaeus \& Håkanson 2004; Krivtsov et al. 2001).

- A more ambiguous modelling method is creation of tactical models neglecting several basic determining factors. Although focusing on the essence and neglecting several basic processes still they provide useful information about the operation of the system in general. Special emphasis is put on the predictive applicability rather than biological interpretation of mathematical operations (Hufnagel \& Gaál 2005; Sipkay \& Hufnagel 2006; 2007; Sipkay et al. 2008).

\section{Modelling of environmental changes}

As a result of climate change (e. g. rising temperatures, changing precipitation), models aimed at describing changes in the physical state of freshwaters quantitatively provide a firm basis for the understanding of the trends in ecological changes. Such studies apply internationally recognized GCM-based RCMs in every case. To illustrate this point take the so-called PROBE model (physical model set up for a lake) (Blenckner et al. 2002), which provided knowledge on the effects of climate change on the ecological state of Lake Erken in Sweden. It was tested on 30-year field data successfully and seems to be suited to forecast the physical changes and their degree. Beyond rising water temperatures, changes include shortening of ice cover periods, decrease in total ice cover events and change in the mixing regime. If it comes true, it will result in enhanced nutrient cycle and productivity.

Hostetler \& Small (1999) tried to describe general effects of climate change within a physical model for lakes. The paper deals with physical responses (temperature, mixing, ice cover, evaporation) of North American lakes characterizing their spatial patterns quantitatively. The model was run on theoretical lakes of different region, depth and transparency. Results suggested extreme rise in temperatures (in certain cases water temperatures above $30{ }^{\circ} \mathrm{C}$ in summer) meaning major disturbance of aquatic ecosystems.

There are models destined for predicting the temperature rises of rivers. Such a model is the numeric river model of Gooseff et al. (2005), which aimed at forecasting the potential influence of global warming on a shallow reservoir's water temperatures (Lower Madison River, Montana, USA). The study draws attention to water temperature as a critical factor for fish, thus rising temperatures may harm fish stocks strongly.

Some studies try to describe environmental changes by means of a model system considering not only rise in temperatures and changing precipitation conditions, but also change in chemical factors within a whole water system. Such one includes Mike 11TRANS model system (Andersen et al. 2006) the goal of which is the prediction of changes in hydrological and nutrient conditions in the River Gjern and its catchment area. It is based on GCM of A2 climate change scenario (2071-2100 years) downscaled 
for the given region. The model system contains „rainfall-runoff” and „statistical nutrient loss" models by the help of which we are able to make quantitative predictions for the changes (\%) in hydrological and nutrient conditions expected in the catchment area (including seasonal aspects as well). Results suggest that average annual total nitrogen (TN) export may increase by $7.7 \%$.

\section{Simple models of special issues}

Essentially, the model of Matulla et al. (2007) aimed at modelling environmental changes through the example of fish assemblages in an upper alpine river by modelling rising water temperatures and drawing conclusions on fish assemblages. The speciality of the approach is that the authors created a model for an index characterizing zones from fish faunistical point of view, so the model is capable of generating quantitative data of changes expected in fish assemblages. Due to the fish faunistical data relative to certain zones of river sections, present approach provides a broader picture of the changes expected in the habitat. Study area was selected in accordance with the objectives i. e. zones easy to separate, and this was the River Mur in Austria. Water temperatures were modelled on the basis of air temperatures considering current velocity as well. Temperature and precipitation data of climate change scenarios (for the period 2027-2049) downscaled for the sampling site were used for making predictions for the future. Fish Zone Index (FiZI) (Schmutz et al. 2000) was used for modelling the fish fauna. This index assigns numbers to seven biocoenotical regions (Illies \& Botosaneau 1963), which are the equivalents of the zones roughly. A species-specific index was introduced $\left(\mathrm{FI}_{\mathrm{sp}}\right)$ indicating the preferences of species for river zones. By the help of the $\mathrm{FI}_{\mathrm{sp}}$ index values of FiZI were calculated, which is the indicator of the species composition. Results suggest a $70 \mathrm{~m}$ translocation of fish assemblages owing to rise in water temperatures and change in yearly cycle of current velocity. Such conditions favour cyprinid species over salmonid ones. Hyporhithal zone - equivalent of grayling zone - may be replaced by epipotamal zone - equivalent of barbel zone. As a consequence, species characteristic for the River Mur such as Thymallus thymallus or Hucho hucho seem to be in danger because of other species coming to the front. The expected changes are rather unfavourable since - among other things - salmonid species are of major interest from the point of view of fishing.

Through considering climatic factors determining spatial patterns of fish assemblages, there have been some models (e. g. Flebbe et al. 2006) using climate change scenarios indicating that the approach presented above is not completely unique.

Due to the difficulties of complex ecosystem models, and minimalist models being too specific, new trends appeared in modelling studies searching for possible ways between them. Peeters et al. (2007) proposed a mechanistic model for phytoplankton, which does not aimed to describe the behaviour of the whole food web within the year, rather focuses on winter and spring periods only, but considers all important factors within this time. It is worth mentioning that within this period, phytoplankton is limited by light primarily, nutrients are of minor importance and food web is less complex. The model was not created for answering climate change related questions, however, it is of major importance in the topic covered due to its dependence on meteorological conditions. The objective of the study was the simulation of phytoplankton production and that of variation in its timing between years. The model was constructed on the basis of samples taken in Upper Lake Constance. The large and deep (average depth 
$102 \mathrm{~m}$ ) lake of perialpine origin experienced eutrophication and reoligotrophication in the last century. The lake has been the objective of studies for a long time, thus its biological background is widely known (Bäuerle \& Gaedke 1998). The model was constructed on the basis of samples taken between 1979 and 1994. Both meteorological factors (wind speed, wind direction, air temperature, solar radiation, precipitation, ice cover) and biotic factors (mainly phytoplankton and zooplankton data series) were involved in the model. 1-D mechanistic phytoplankton model was combined with 1-D hydrodynamical model. Basically, mechanistic phytoplankton model includes chlorophyll-a production and loss relative to the vertical water column including also a large set of parameters. Several parameters were constant (e. g. respiration rate, maximum specific production rate at $10{ }^{\circ} \mathrm{C}$ ), thus certain phenomena such as acclimatization and changes in community structure were neglected. However, zooplankton grazing effect was included in the model. Through the 1-D hydrodynamical model temperature stratification was demonstrated successfully. Results suggest that timing of the initial phytoplankton growth in deep monomictic lakes is determined by turbulent diffusion in the water column. Further factors included in the analysis (e. g. photosynthetically active radiation or water temperature) were of minor importance. These findings are of major importance from the point of view of climate change, since variance in mixing dynamics between years is correlated with meteorological conditions. Climate change affecting winter and spring periods may alter the timing of phytoplankton bloom fundamentally. As a consequence, the study draws attention to the significance of winter period of low biological activity.

\section{Model systems of general practicability, ecosystem models}

Models of general applicability able to describe different water bodies are entitled to greater interest as compared to models of specific habitats e. g. a lake. These studies are not focusing on special issues within a simplified modelling framework rather combined into a complex model system focusing on essential processes. There are models that were not created for testing the influence of global warming, rather focused on the description of a complex system (e. g. a lake) involving environmental variables, nutrients.

To illustrate this point, take the PCLake ecosystem model developed for shallow lakes, which were applied in the field of eutrophication (Janse et al. 1992; Janse \& Liere 1995), but were also applied for studying the effects of climate change later (Mooij et al. 2007). Impacts of temperature rise on biotic and abiotic components were modelled and other consequences (e. g. increase of winter precipitation) of climate change were also examined in shallow lakes in the Netherlands. The model was created for the simulation of nutrient load and food web dynamics on the basis of data series (nutrient, transparency, chlorophyll, vegetation) obtained over 40 shallow lakes. The effects of warming expected were investigated by the help of 4 temperature scenarios. Critical level of nutrient load was defined during eutrophication when clear water state turns into turbid state and during (re)oligotrophication when its contrary can be observed. The complexity of the model is best highlighted by the wide and large set of input parameters. Main input parameters included water inflow, infiltration or seepage rate, nutrient loading $(\mathrm{N}, \mathrm{P})$, particulate loading, temperature, light dimension (depth and dimensions of lake), size of the marsh zone, loading history (initial conditions). A total of 14 temperature dependent component were included in the model (Table 2.) from 
which 6 were abiotic and 8 biotic. Abiotic processes were described with exponential functions, biotic components were introduced with Gauss-curves by defining their temperature optimum. Macrophytes were simulated through two exponential functions as an optimum function. Respiration got higher values of $\mathrm{Q}_{10}$ than production.

Table 2. Temperature dependent components and their parameters in the PCLake ecosystem model (Mooij et al. 2007)

\begin{tabular}{|c|c|c|}
\hline Abiotic process & Temperature coefficient $\mathrm{c}$ & \\
\hline Denitrification & 1,07 & \\
\hline Diffusion & 1,02 & \\
\hline $\begin{array}{l}\text { Mineralization in sediment } \\
\text { or water }\end{array}$ & 1,07 & \\
\hline Nitrification & 1,08 & \\
\hline Reaeration & 1,024 & \\
\hline Sedimentation & 1,01 & \\
\hline Biotic component & $\begin{array}{c}\text { Optimum temperature } \\
\mathbf{T}_{\mathbf{o p t}, \mathrm{j}} \\
\end{array}$ & $\begin{array}{c}\text { Width around optimum } \\
\text { temperature } \mathbf{T}_{\text {sigma,j }}\end{array}$ \\
\hline Diatoms & $18^{\circ} \mathrm{C}$ & $20^{\circ} \mathrm{C}$ \\
\hline Green algae & $25{ }^{\circ} \mathrm{C}$ & $15^{\circ} \mathrm{C}$ \\
\hline Cyanobacteria & $25{ }^{\circ} \mathrm{C}$ & $12{ }^{\circ} \mathrm{C}$ \\
\hline Zooplankton & $25^{\circ} \mathrm{C}$ & $13{ }^{\circ} \mathrm{C}$ \\
\hline Zoobenthos & $25{ }^{\circ} \mathrm{C}$ & $16^{\circ} \mathrm{C}$ \\
\hline $\begin{array}{l}\text { Planktivorous and } \\
\text { benthivorous fish }\end{array}$ & $25^{\circ} \mathrm{C}$ & $10{ }^{\circ} \mathrm{C}$ \\
\hline Piscivorous fish & $25^{\circ} \mathrm{C}$ & $10^{\circ} \mathrm{C}$ \\
\hline Macrophytes & $Q_{10, \text { prod }}=1,2$ & $Q_{10, \text { resp }}=2,0$ \\
\hline
\end{tabular}

Four scenarios were used from which the first one served as control, further three calculated with (1) $3{ }^{\circ} \mathrm{C}$ rise in temperatures throughout the year, (2) summer, (3) winter temperature rises only.

According to the findings of PCLake ecosystem model and scenarios, global warming has a strongly negative effect on the status of shallow lakes in the temperate region. Several mechanisms will occur together such as increase in loading and decrease in critical nutrient level of eutrophication. As a result of these, lakes investigated are more likely to turn into turbid state. In line with these, basic changes include increased phytoplankton growth rate and increased availability of phosphorus (owing to increased summer mineralization and temperatures). Rising water temperatures favour phytoplankton mainly cyanobacteria. Enhanced dominance of cyanobacteria draws attention to cumulative risks of climate change in itself. Winter temperatures seem to have significant importance as well. Greatest changes were detected at scenarios with warm winter, whereas scenarios with warm summer showed similar outcomes to the control scenario. This phenomenon is enhanced by changes observed in other trophic levels: e. g. abundance of planktonivorous fish is expected to increase at warm periods, which would result in enhanced predation pressure on zooplankton. The study demonstrated that a complex physical-biological ecosystem model can be well adapted to explore the possible effects of climate change and it draws attention to negative aspects of changes (Mooij et al. 2007).

Model predictions show very similar features. The phytoplankton model PROTECH forecasts enhanced spring phytoplankton bloom with increasing dominance of cyanobacteria on the basis of field data and RCMs downscaled to the region of Lake Bassenthwaite (Elliot et al. 2005). However, summer bloom is expected to disappear 
more rapidly due to the nutrient limitation explained by enhanced spring phytoplankton production, thus total productivity will not change.

The majority of ecosystem models are applied to small shallow lakes. As far as large lakes are concerned - ranging from shallow eutrophic to deep oligotrophic ones -, fewer studies can be found (Blenckner 2008). Large lakes response to external effects more slowly due to increased water residence time (Tilzer \& Bossard 1992), thus the influence of climate change cannot be compared with those of small lakes at all points.

The mechanistic phosphorus model (LEEDS) of different Swedish lakes combined with a physical lake model is a good example of complex models with wider applicability (Malmaeus \& Håkanson 2004; Malmaeus et al. 2005). In order to predict future states regional climate change scenarios were used. Simulations showed smaller Lake Erken to be more reactive to warming - due to increased dissolved phosphorus concentration in spring - than Lake Mälaren (third largest lake in Sweden). These findings support evidence for significance of inner processes. Phytoplankton biomass of Lake Erken is phosphorus limited. These results are true for other similar lakes with increased water residence time pointing out that through climate change eutrophication may cause serious problems in several habitats. Also further examples can be found for models of wider applicability. Such models are LakeWeb (Håkanson \& Boulion 2002) and Rostherme models (Krivtsov et al. 2001).

Some papers draw attention to lack of process-based models (Blenckner 2008; Komatsu et al. 2007) including models with (temporal) dynamics of interactions between defined entities (Minns 1992). However, these models can be the keys of prediction contrary to statistical models, which are only valid within a current range (Klepper 1997). The water temperature-ecosystem model WT-ECO (Hosomi et al. 1996) can be regarded as a model of that kind, however, it does not apply GCM scenarios, only calculates with $2-4{ }^{\circ} \mathrm{C}$ rise in air temperatures. Although applying climate change scenarios, the LEM model (mathematical eutrophication model) of Hassen et al. (1998) is not able to describe long-term effects of climate change. Its input parameters include atmospheric, chemical and hydrological factors distributed vertically, output parameters are phytoplankton growth rate and dissolved oxygen concentration.

A complex model system was developed in order to examine the long-term effects of climate change on water quality in Shimajigawa reservoir, Japan (Komatsu et al. 2006; 2007). Expected future climate were described on the grounds of A2 GCM based regional climate models for the period 2091-2100, taking the period of 1991-2001 as control. The model system consists of two major parts. The first one is a complex water quality model including Flow and Transport Model, Water-Sediment Model and Ecological Model from which the latter one is based on several parameters. The second part is the Runoff Model considering inflow, precipitation and outflow. The large number of components and connections between them (Figure 1) indicate that the water body has been thoroughly studied and monitored for a long time.

The model forecasts increase in trophic status with rising temperatures providing one more example for the fact that climate change may induce negative processes in aquatic ecosystems through increased phytoplankton production primarily. Temperature related processes altogether would result in a more strongly eutrophicated state. Such processes include elongation of thermally stratified periods, increased oxygen demand of aerobic decomposition, facilitated phosphorus release from the sediment and its increased concentration in the hypolimnion. 

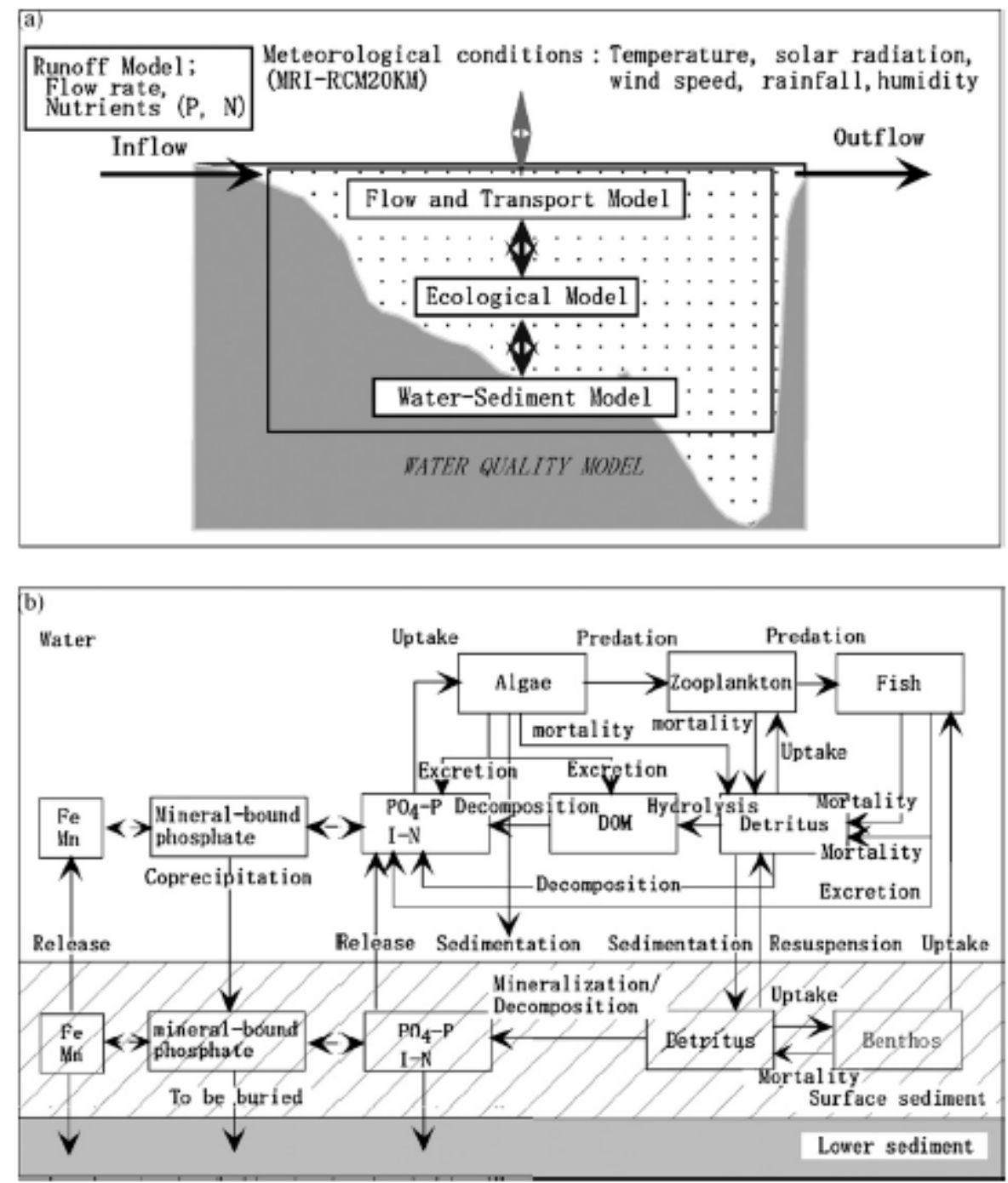

Figure 1. Components of the water quality model combined with the runoff model developed for a West Japanese reservoir (a), compartments and connections of its integrated ecological model (b) (Komatsu et al. 2007)

The above-mentioned examples showed evidence of the capability of ecosystem models to define the effects of rising temperatures on aquatic freshwater systems in a detailed way through describing basic connections quantitatively. However, the applicability of such models to other water bodies presents some difficulty even within similar habitats. Biggest problem one has to face is lack of data and their availability (Porter et al. 2005). On the one hand, data already presented is not easy to obtain, on the other hand, long-term data sets are not achieved on the basis of the same methodology in each cases. What is more, complex models require data often not available regarding several water bodies. In most cases, this is why model systems describing general phenomena cannot be adapted to several habitats of major importance. 


\section{Possibilities of tactical modelling (i. e. simplified modelling of seasonal dynamics)}

As mentioned above, there are numerous approaches so as to describe the trends in change of physical, chemical features, population or community components of freshwaters under climate change by means of model construction. Some models consider the habitat (lake, river) as a physical unit and try to describe the change in physical parameters, thus we can make statements of communities living in the water on the basis of our recent knowledge. Certain models focus on special issues of a defined water body, which can be very useful from the point of view of the given question, but examination of their methodological approach provides possibilities of applicability to other issues or habitats. Complex ecosystem models incorporating most basic processes of freshwater systems may be the keys of the comprehensive understanding of the effects of climate change. However, modelling methodology of climate change related research cannot be regarded as adequate yet. The root of the problem is lack of synthetizing models and their practicability. These models require quite a lot of information of which we are not familiar with definitely. On the other hand, often we manage to set up a complex model, but its parameters cannot be determined due to lack of field data. Thus, instead of such strategic models often tactical ones are used, which focus on the essence and may neglect some important pieces of information at the same time. Still they can be useful tools to understand the general functioning of the system. This is achieved through stressing the factor regarded as the most crucial and neglecting the other processes. It raises the question whether it is meaningful to stress one factor as the most important one, on the basis of which the seasonal dynamics of the assemblage investigated can be described. Several authors draw attention to the central regulatory role of temperature. According to Christou \& Moraitou-Apostolopoulou (1995) temperature is the main factor accountable for the temporal variation of mesozooplankton. Iguchi (2004) and Dippner et al. (2000) got to similar results. Temperature correlated positively or negatively with almost each copepod species depending on the ecological need of the species given (Christou, 1998). Long-term changes in densities of numerous species of Copepoda were related to temperature and salinity (Viitasalo et al., 1990; Meise-Munns et al., 1990; Baranovic et al., 1993). Consequently, stressing temperature as the most important regulating factor seems to be relevant. By taking into consideration the failures and assumptions of the model it is possible to explore the effects of climate change most likely to occur (Hufnagel \& Gaál 2005). In order to model the seasonal dynamics of population collectives model system already presented can be used (Ladányi et al. 2003). When using long-term data to construct models, predictive applicability has priority over biological interpretation of mathematical operations through stressing one regulating factor as the most essential and neglecting the other ones. Emphasizing temperature as the most important factor seems to be obvious when modelling seasonal dynamics. In this case, the model hypothesizes temperature to be the only regulating factor, thus the pattern is determined by the daily temperatures, other effects (e. g. trophic connections and other interactions between populations) may appear within this term or hidden.

On the basis of the above-mentioned conception, a rather simple mathematical model can be created of which the essence is: daily abundance can be calculated by multiplying abundance of the previous day by a temperature function (Hufnagel \& Gaál 2005; Sipkay \& Hufnagel 2006; 2007; Sipkay et al. 2007, 2008.a-b). Running the model with the data series of different climate change scenarios we get a picture of future abundance of the investigated species, which should be handled watchfully. The goal of 
the approach is not prediction, rather the comparative assessment of different climate change scenarios within the framework of a realistic model situation.

The objects of modelling can be a group of high abundance playing a major role in the aquatic food web (e. g. total zooplankton abundance), and also abundance or biomass of a dominant species (Vadadi et al. 2007). Another approach includes modelling the seasonal dynamics of some coenological index. Such approach was proposed by Sipkay \& Hufnagel (2007) through a case study performed in Lake Balaton. The authors introduced the „Coenological Intensity Index” (CII) characterizing the macroinvertebrate assemblage as a unit. This index considers abundances, biovolume and Shannon diversity simultaneously and it was the object of modelling as well.

In the simplest case, the multiplier describing temperature dependence is determined by constants related to temperature intervals (Sipkay \& Hufnagel, 2006; Vadadi et al. 2007). These constant values are the model parameters, which can be optimized with the MS Excel Solver program when fitting the data. However, instead of temperature intervals being often distributed in a complex way, we supposed that the temperature reaction-curve must be the sum of optimum-curves, since temperature optimum-curves of the different developmental stages of the species in question or its distinct subpopulations can be summed. Thus, the values of the multiplier are determined by a continuous function (sum of normal distributions) depending on the daily temperatures.

Experimental ponds are the best objects for describing and modelling the connection between weather conditions and seasonal dynamics in a more exact way through minimizing the number of external regulating factors. This means a transitional approach between laboratory experiments and field observations. Such experiments have been conducted in an artificial pond in Budapest, Hungary. Phytoplankton, zooplankton and macroinvertebrates have been sampled quantitatively and semiquantitatively at regular frequencies of one or two weeks. Through this sampling design (sampling different assemblages regularly in a harmonized way) the food web model can also be constructed. First attempt of that was a model in which phytoplankton abundance was determined by temperatures, and abundances of zooplankton groups and that of a dominant macroinvertebrate species (Vadadi et al. 2008). Even if we do not understand exactly the reason for temperature being the most important regulating factor, still we can make predictions for the periods 2050 and 2070-2100 respectively as regards abundances by running the model with the data series of climate change scenarios. Results suggest that climate change will influence algae and zooplankton in a similar way i. e. decreasing abundances, abundance peaks will occur earlier within years.

One failure of the models illustrated above may be that they are not reliable adequately due to the relatively short-term data series available for fitting. However, the approach mentioned above was applied to long-term data series of the Hungarian Danube Research Station (at Göd) including the period of 1981-1994. First, a model was created describing the seasonal dynamics of a copepod species of high abundance being presented throughout the year on the basis of the above-mentioned database (Sipkay et al. 2008). Results indicated 1-1.5 month shift in the abundance peak towards earlier dates.

Seasonal dynamics of phytoplankton in the River Danube was described by means of a more complex model (Sipkay et al. 2008.b). A detailed (taxa were identified to species level), long-term (1983-1996) database with sampling frequency of weekly intervals is 
available for the phytoplankton of the River Danube at the area of Göd. In addition, the temperature dependence of the phytoplankton group located on the basal level of food web is more direct and the number of further regulating factors are less than those of zooplankton and macroinvertebrates. Phytoplankton is not limited by nutrients, rather temperatures and light play a major role in determining seasonal dynamics of algae in the River Danube (Kiss 1994). Since this being the case, it is necessary to include these regulating factors into the phytoplankton model. The model is the linear combination of the temperature optimum-curves of 12 theoretical species. These 12 theoretical species characterized by different temperature optimums and tolerance intervals can multiply at various rates. However, the model includes not only a temperature dependent multiplier but also a light dependent one (through a minimum function), thus the multiplier with lower values counts in each case. Light dependent growth rate involves the environment's carrying capacity meaning a top-down limit for phytoplankton. It can be described with a sinus curve of which the parameters were adjusted considering all-time minimum and maximum abundances of phytoplankton, and order of magnitude of difference between winter and summer maximum values. This design represents differences in lighting periods during the year. Based on the simulation of phytoplankton assemblages in the River Danube, average plankton production is not likely to alter significantly, but on the whole, rather increasing abundance is expected as a consequence of climate change. However, between years variability will increase drastically and significantly.

\section{Summary, discussion}

Similarly to ecological surveys, research on the effects of climate change on freshwater ecosystems can be divided into three methodological approaches. First, we have the possibility to explore the influence of climate change in the past by means of field observations. Fundamentally, paleoecological surveys also range within the abovementioned stream. Secondly, particularly regarding some minor phenomena, experiments under controlled conditions can shed some more light on the possible effects of climate change. Thirdly, model construction includes creating exact mathematical description (mathematical model) of the simplest theory of the phenomenon in question by means of basic biological phenomena and hypotheses. The kernel of the approach can be described by a logical cycle including testing (contrasting with case studies) and improving (development and fitting) of the model. By the help of this methodology, we get a more and more realistic theory of the investigated phenomenon, however, at an early stage we only use some parts of information available.

Each approach mentioned above has its advantages and disadvantages. Reliable, watchfully overseen, certified knowledge can be provided by experiments. When the research objective is a rather complex phenomenon, having importance in application as well, observation and detailed description of it is required in order to formulate realistic hypotheses. Field research in ecology with complex approach is constrained to present single data and correlation between some variables, otherwise such complex hypotheses would be formulated that it would be almost impossible to test them. In order to open up the reasons behind complex phenomena it is essential to formulate hypotheses within simulation models, because in absence of that it would be impossible to choose between alternative hypotheses. Another advantage of the simulation method is that it may point 
out misleading interpretation, which has the potential to become a problem both during data analysis (approach 1) and when combining the results of experiments (approach 2).

The main potentials of modelling were reviewed ranging from the physical environment to aquatic communities and their elements. The latter provides relatively exact predictions for future changes in aquatic systems by the help of climate change scenarios. There are complex ecosystem models that were not created for testing the influence of global warming, however, by taking into consideration a large set of environmental variables, they are capable of studying climatic changes as well. Mostly, the outputs are consistent with the physical changes (change in ice cover and mixing patterns) expected. To recap what has been reviewed, global warming may create eutrophication-like features in the water bodies of the temperate zone, particularly in lakes, which has the potential to become a very serious problem.

Since synthetized models are rather difficult to handle and require quite large series of data, the authors proposed a more simple modelling approach, which is capable of examining the effects of global warming specifically. Predictive application of the model is favoured over ecological interpretation of mathematical procedures when modelling the seasonal dynamics within a simplified framework. When stressing few factors - often temperature only - we expect factors not included in the model to appear hidden or within the temperature term. Such models were fitted to the seasonal dynamics data series of aquatic organisms successfully. Considering temperature as the only factor determining seasonal dynamics, we are interested in whether temperature in itself may create similar pattern to the observed one. After fitting the model successfully to the data series of several years we get a plausible answer of it. On the basis of such models, populations of certain organisms are expected to peak earlier during the season, whereas the trend in changes of total abundance is varying. Furthermore, modelling the phytoplankton in the River Danube indicates large fluctuations between years due to the global warming. These models may support evidence of such future changes that we would not be able to forecast on the basis of our recent knowledge on the environmental changes.

Acknowledgements. This research was supported by the "Bolyai János" Research Fellowship (Hungarian Academy of Sciences) and the Research Assistant Fellowship Support (Corvinus University of Budapest).

\section{REFERENCES}

[1] Allan, J.D., Palmer, M., Poff, N.L. (2005): Climate change and freshwater ecosystems. In: Lovejoy, T.E., Hannah, L. (eds): Climate change and biodiversity. Yale University Press, New Haven, CT, pp. 274-295.

[2] Adrian, R., Deneke, R., Mischke, U., Stellmacher, R., Lederer, P. (1995): A long-term study of the Heilingensee (1975-1992). Evidence for effects of climatic change on the dynamics of eutrophied lake ecosystems. - Archiv fur Hydrobiol 133: 315-337.

[3] Adrian, R., Walz, N., Hintze, T., Hoeg, S., Rusche, R. (1999): Effect of ice duration on the plankton succession during spring in a shallow polymictic lake. - Freshwater Biology 41: 621-623.

[4] Andersen, H.E., Kronvang, B., Larsen, S.E., Hoffmann, C.C., Jensen, T.S., Rasmussen, E.K. (2006): Climate-change impacts on hydrology and nutrients in a Danish lowland river basin. - Science of the Total Environment 365: 223-237. 
[5] Anneville, O., Gammeter, S., Straile, D. (2002): Phosphorus decrease and climate variability: mediators of synchrony in phytoplankton changes among European perialpine lakes. - Freshwater Biology 50(10): 1731-1746.

[6] Anneville, O., Molinero, J.C., Souissi, S., Balvay, G., Gerdeaux, D. (2007): Long-term changes in the copepod community of Lake Geneva. - Journal of Plankton Research 2007. 29(1): 49-59.

[7] Arashkevich, E., Wassmann, P., Pasternak. A., Riser, C. W. (2002): Seasonal and spatial changes in biomass, structure, and development progress of the zooplankton community in the Barents Sea. - Journal of Marine Systems 38: 125-145.

[8] Baltz, D.M., Moyle, P.B. (1993): Invasion resistance to introduced species by a native assemblage of California stream fishes. - Ecol Appl 3: 246-255.

[9] Baranovic, A., Solic, M., Vucetic, T., Krstulovic, N. (1993): Temporal fluctuations of zooplankton and bacteria in the middle Adriatic Sea. - Marine Ecology Progress Series 92: 65-75.

[10] Barrow, E.M., Hulme, M., Semenov, M.A., Brooks, R.J. (2000): Climate change scenarios. - In T. E. Downing, P. A. Harrison, R. E. Butterfield, \& K. G. Lonsdale (Eds.), Climate change, climatic variability and agriculture in Europe: An integrated assessment (pp. 11-27). Oxford, UK: University of Oxford.

[11] Bäuerle, E., Gaedke, U. (1998): Lake Constance - characterization of an ecosystem in transition. - In E. Ba“ uerle, U. Gaedke and E. Stuttgart [eds.], Schweizerbartsche Verlagsbuchhandlung. Arch. Hydrobiol. Spec. Issues Adv. Limnol. 53: 1-610.

[12] Bernot, R. J., Dodds, W. K., Quist, M. C., Guy, C. S. (2004): Spatial and temporal variability of zooplankton in a great plains reservoir. - Hydrobiologia 525: 101-112.

[13] Blenckner, T., Omstedt, A., Rummukainen, M. (2002): A Swedish case study of contemporary and possible future consequences of climate change on lake function. Aquatic Sciences 64(2): 171-184.

[14] Blenckner, T. (2008): Models as tools for understanding past, recent and future changes in large lakes. - Hydrobiologia 599: 177-182.

[15] Carpenther, S.R., Fisher, S.G., Grimm, N.B., Kitchell, J.F. (1992): Global change and the freshwater ecosystems. - Annual Reviews of Ecological Systems 23: 119-139.

[16] Charlson, R.J., Lovelock, J.E., Andreae, M.O., Warren, S.G. (1987): Oceanic phytoplankton atmospheric sulfur, cloud albedo and climate. - Nature (London) 326: 655-661.

[17] Christensen, J.H. (2005): Prediction of Regional scenarios and Uncertainties for Defining European Climate change risks and Effects. - Final Report. DMI, Copenhagen.

[18] Christoffersen, K., Andersen, N., Sondergaard, M., Liboriussen, L., Jeppesen, E. (2006): Implications of climate-enforced temperature increase on freshwater pico- and nanoplankton populations studied in artificial ponds during 16 months. - Hydrobiologia 560: 259-266.

[19] Christou, E. D., Moraitou-Apostolopoulou, M. (1995): Metabolism and feeding of mesozooplankton at the eastern Mediterranean (Hellenic coastal waters). - Marine Ecology Progress Series 126: 39-48.

[20] Cohen, A.S. (2003): Paleolimnology: The Hystory and Evolution of Lake Systems. Oxford University Press, Oxford, $528 \mathrm{pp}$.

[21] Cushing, D.H. (1975): Marine ecology and fisheries - Cambridge, Cambridge University Press

[22] Dawidowicz, P., Gliwicz Z.M., Gulati, R.D. (1988): Can Daphnia prevent a blue-green algal bloom in hypertrophic lakes? A laboratory test. - Limnologica (Berlin) 19: 21-26.

[23] De Senerpont Domis, L.N., Mooij, W.M., Huisman, J. (2007): Climate-induced shifts in an experimental phytoplankton community: a mechanistic approach. - Hydrobiologia 584: 403-413.

[24] Dippner, J. W., Kornilovs, G., Sidrevics, L. (2000): Long-term variability of mesozooplankton in the Central Baltic Sea. - Journal of Marine Systems 25: 23-31. 
[25] Dubois, D. (1975): A model of patchiness for prey-predator plankton populations. - Ecol. Model. 1: 67-80.

[26] Duinker, J., Wefer, G. (1994): Das CO2-problem und die Rolle des Ozeans. Naturwissenschaften 81: 237-242.

[27] Eaton, J.G., Scheller, R.M. (1996): Effects of climate warming on fish thermal habitat in streams of the United States. - Limnol. Oceanogr. (41): 1109-1115.

[28] Elliott, J.A., Thackeray, S.J., Huntingford, C., Jones, R.G. (2005): Combining a regional climate model with a phytoplankton community model to predict future changes in phytoplankton in lakes. - Freshwater Biology 50: 1404-1411.

[29] Felföldy L. (1981): A vizek környezettana. - Általános hidrobiológia. Mezőgazdasági Kiadó, Budapest

[30] Ficke, A.D., Myrick, C.A., Hansen, L.J. (2007): Potential impacts of global climate change on freshwater fisheries. - Rev. Fish. Biol. Fisheries 17: 581-613.

[31] Flanagan, K.M., McCauley, E., Wrona, F., Prowse, T. (2003): Climate change: the potential for latitudinal effects on algal biomass in aquatic ecosystems. - Can. J. Fish Aquat. Sci. 60: 635-639.

[32] Flebbe, P.A., Roghair, L.D., Bruggink, J.L. (2006): Spatial modeling to project southern Appalachian trout distribution in a warmer climate. - Trans. Am. Fish. Soc. 135: 13711382.

[33] Fleming, R.H. (1939): The control of diatom populations by grazing. - J. Cons. Int. Explor. Mer 14: 210-227.

[34] Fritsch A.J. (1872): Die Wirbeltiere Böhmens. Ein Verzeichnis aller bisher in Böhmen beobachteten Säugetiere, Vögel, Amphibien und Fische. - Arch Naturwissensch Landesdurchforsch Böhmen 2: 1-152.

[35] Geadke, U., Straile, D., Pahl-Wostl, C. (1998): Trophic structure and carbon flow dynamics in the pelagic community of a large lake. - In: Polis, G.A., Winemiller, K.O. (eds), Food Webs Integration of Pattern and Dynamics. Chapmann and Hall, pp. 60-71.

[36] Gerten, D., Adrian, R. (2001): Differences in the persistency of the North Atlantic Oscillation signal among lakes. - Limnology and Oceanography 46: 448-455.

[37] Gliwicz, Z.M., Lampert, W. (1990): Food thresholds in Daphnia species in the absence and presence of bluegreen filaments. - Ecology 71: 691-702.

[38] Gooseff, M.N, Strzepek, K., Chapra. S.C. (2005): Modeling the potential effects of climate change on water temperature downstream of a shallow reservoir, Lower Madison River, MT. - Climatic Change 68(3): 331-353.

[39] Gragnani, A., Scheffer, M., Rinaldi, S. (1999): Top-down control of cyanobacteria: A theoretical analysis. - Am. Nat. 153: 59-72.

[40] Grover, J.P., Chrzanowsky, T.H. (2005): Seasonal dynamics of phytoplankton in two warm temperate reservoirs: association of taxonomic composition with temperature. Journal of Plankton Research 27: 1-17.

[41] Gulati, R. D., Siewertsen, K., Postema, G. (1982): The zooplankton: its community structure, food and feeding, and role in the ecosystem of Lake Vechten. - Hydrobiologia 95: 127-163.

[42] Gulland, J.A. (1977): Fish population dynamics (London: Wiley)

[43] Gyllström M., L., A. Hansson, E., Jeppesen, F., García-Criado, E., Gross, K., Irvine, T., Kairesalo, R., Kornijow, M. R., Miracle, M., Nykänen, T., Nőges, S., Romo, D., Stephen, E. Van Donk, B. Moss (2008): The role of climate in shaping zooplankton communities of shallow lakes. - Limnol. Oceanogr. 50(6): 2008-2021.

[44] Hays, G. C., Richardson, A. J., Robinson, C. (2005): Climate change and marine plankton. - Trends in Ecology and Evolution 20(6): 337-344.

[45] Harrison, P.A., Butterfield, R.E., Downing, T.E. (2000): The CLIVARA project: Study aims and methods. In T. E. Downing, P. A. Harrison, R. E. Butterfield, \& K. G. Lonsdale (Eds.) - Climate change, climatic variability and agriculture in Europe: An integrated Assessment (pp. 3-10). Oxford, UK: University of Oxford. 
[46] Hartman, M.D., Baron, J.S., Ojima, D.S. (2006): Application of a coupled ecosystemchemical equilibrium model, DayCent-Chem, to stream and soil chemistry in a Rocky Mountain watershed. - Ecological Modelling 200: 493-510.

[47] Hassen, H., Hanaki, K., Matsuo, T. (1998): A modeling approach to simulate impact of climate change lake water quality: phytoplankton growth rate assessment. - Water Sci. Technol. 37(2): 177-185.

[48] Håkanson, L., Boulion, V.V. (2002): The Lake Foodweb. - Backhuys Publishers, Leiden, $344 \mathrm{pp}$.

[49] Hensen, V. (1892): Ergebnisse der in dem Atlantischen Ocean von Mitte Juli bis Anfang November 1889 ausgeführten Plankton - Expedition der Humboldt - Stiftung (Kiel and Leipzig)

[50] Herodek S. (1986): Phytoplancton Changes During Eutrophication and $\mathrm{P}$ and $\mathrm{N}$ Metabolism. - In: L. Somlyódy and G. van Straten (eds.) Modeling and Managing Shallow Lake Eutrophication, Springer Verl. Berlin pp. 183-204.

[51] Hosomi, M., Okada, M., Sudo, R. (1996): Development of the phosphorus dynamics model in sediment-water system and assessment of eutrophication control program. Water Sci. Technol. 24(6): 339-348.

[52] Hostetler, S.W, Small, E.E. (1999): Response of North American freshwater lakes to simulated future climates. - Journal of the American Water Resources Association 35(6): $1625-1637$.

[53] Huet, M. (1949): Apercu des relations entre la pente et les populations piscicoles des eaux courantes. - Schweiz Z Hydrol (11): 332-351.

[54] Hufnagel L., Mészáros Z., Gaál M. Ferenczy A. (1999): Temporal Spatial Patterns of Noctuinae Communities (Lep. Noctuidae) in Hungarian Apple Orchards (Apple Ecosystem Research) - Acta Phytopathologica et Entomologica Hungarica 34(4): 341353.

[55] Hufnagel L., Gaál M. (2005): Seasonal dynamic pattern analysis service of climate change research. - Applied Ecology and Environmental Research 3(1): 79-132.

[56] Hufnagel L., Sipkay Cs., Drégely-Kis Á., Farkas E., Türei D., Gergócs V., Petrányi G., Baksa A., Gimesi L., Eppich B., Dede L., Horváth L. (2008): Klímaváltozás, biodiverzitás és közösségökológiai folyamatok kölcsönhatásai. - In: Harnos Zs., Csete L. (szerk) (2008): Klímaváltozás: Környezet-Kockázat-Társadalom (Kutatási eredmények). Szaktudás Kiadó Ház, Budapest. pp. 227-264.

[57] Huisman, J., Arrayas, S., K., Ebert, U., Sommeijer, B. (2002): How do sinking phytoplankton species manage to persist? - Am. Nat. 159: 245-254.

[58] Huppert, A., Blasius, B., Stone, L. (2002): A model of phytoplankton blooms. - Am. Nat. 159: 156-171.

[59] Iguchi, N. (2004): Spatial/temporal variations in zooplankton biomass and ecological characteristics of major species in the southern part of the Japan Sea: a review. - Progress in Oceanography 61: 213-225.

[60] Illies, J., Botosaneanu, L. (1963): Problèmes et méthodes de la classification et de la yonation écologique des eaux courantes considerées surtout du point de vue faunistique. Internationale Vereinigung für theoretische und angewandte. Limnologie (12): 1-57.

[61] IPCC (2007, a): Climate Change 2007, Sinthesis Report. - Contribution of Working Group I, II and II to the Fourth Assessment Report of the Intergovernmental Panel of Climate Change. IPCC, Geneva, Switzerland.

[62] IPCC (2007, b): Climate Change 2007. The Physical Science Basis. - Working Group I Contribution to the Fourth Assessment Report of the IPCC. Intergovernmental Panel of Climate Change, Cambridge University Press, New York.

[63] Ivlev, V.S. (1945): Biological productivity of reservoirs; Usp. - Sovrem. Biol. 19: 98120.

[64] Jankowski, T., Livingstone, D.M., Bührer, H., Forster, R., Niederhaser, P. (2006): Consequences of the 2003 European heat wave for lake temperature profiles, thermal 
stability hypolimnetic oxigen depletion: implications for a warmer world. - Limnol. Oceanogr. 51: 815-819.

[65] Janse, J.H., Aldenberg, T., Kramer, P.R.G. (1992): A mathematical model of the phosphorus cycle in Lake Loosdrecht and simulation of additional measures. Hydrobiologia 233: 119-136.

[66] Janse, J.H., Van Liere, L. (1995): PCLake - a modeling tool for the evaluation of lake restoration scenarios. - Water Science and Technology 31: 371-374.

[67] Jensen, H.S., Andersen, F.O. (1992): Importance of temperature, nitrate, and pH for phosphate release from aerobic sediments of four shallow, eutrophic lakes. - Limnology and Oceanography 37: 577-589.

[68] Jeppesen, E., Sondergaard, M., Mortensen, E., Kristensen, P., Riemann, B., Jensen, H.J., Müller, J.P., Sortkjaer, O., Jensen, J.P., Christoffersen, K., Bosselmann, S., Dall, E. (1990): Fish manipulation as a lake restoration tool in shallow, eutrophic temperate lakes 1: cross-analysis of three Danish case studies. - Hydrobiologia 200/201: 205-218.

[69] Kalff, J. (2000): Limnology. - Prentice Hall, Upper Saddle River, New Jersey.

[70] Kiss, K.T. \& Genkal, S. I. (1993): Winter blooms of centric diatoms in the River Danube and in its side arms near Budapest. in. H. van Dam, (ed) Twelfth International Diatom Symposium. Kluwer Academic publishers. - Hydrobiologia 269/270: 317-325.

[71] Kiss, K. T. (1994): Trophic level and eutrophication of the River Danube in Hungary. Verh. Internat.Verein.Limnol. 25: 1688-1691.

[72] Kiss, K. T. (1996): Diurnal change of planktonic diatoms in the River Danube near Budapest (Hungary). - Arch. Hydrobiol. Algol. Studies, 80: 113-122.

[73] Kiss, K.T., Ács, É., Szabó, K.É. (2007): Algák és anyagforgalmi kapcsolataik. pp. 33-49. - In: Nosek J., Oertel N. (szerk.): „A Dunának, mely múlt, jelen s jövendő...”. 50 éves az MTA Magyar Dunakutató Állomása (1957-2007). Szemelvények az Állomás tudományos eredményeiből. MTA ÖBKI - MDÁ, Göd - Vácrátót

[74] Klapper, H. (1991): Control of eutrophication in Inland waters. - Ellis Horwood Ltd., West Sussex, UK.

[75] Klepper, O. (1997): Multivariate aspects of model uncertainty analysis: Tools for sensitivity analysis and calibration. - Ecological Modelling 101: 1-13.

[76] Komatsu, E., Fukushima, T., Shiraishi, H. (2006): Modeling of P-dynamics and algal growth in a stratified reservoir-mechanisms of the P-cycle and interactions between water and sediment. - Ecol. Model. 197: 331-349.

[77] Komatsu, E., Fukushima, T., Harasawa, H. (2007): A modeling approach to forecast the effect of long-term climate change on lake water quality. - Ecol. Model. 209: 351-366.

[78] Köck, G., Triendl, M., Hofer, R. (1996): Seasonal patterns of metal accumulation in Arctic char (Salvelinus alpinus) from an oligotrophic Alpine lake related to temperature. - Can J Fisher Aqua Sci 53: 780-786.

[79] Krivtsov, V., Goldspink, C., Sigee, D.C., Bellinger, E.G. (2001): Expansion of the model 'Rostherne' for fish and zooplankton: Role of top-down effects in modifying the prevailing pattern of ecosystem functioning. - Ecological Modelling 138: 153-171.

[80] Ladányi M., Horváth L., Gaál M., Hufnagel L. (2003): An agro-ecological simulation model system. - Applied Ecology and Environmental Research 1(1-2): 47-74.

[81] Larocque, I., Hall, R.I., Grahn, E. (2001): Chironomids as indicators of climate change: a 100-lake training set from a subarctic region of northern Sweden (Lapland). - Journal of Paleolimnology 23(3): 307-322.

[82] Levin. S.A., Segel, L.A. (1976): Hypothesis for origin of planktonic patchiness. - Nature (London) 259: 659.

[83] Liikanen, A., Murtoniemi, T., Tanskanen, H., Vaisanen, T., Martikainen, P.J. (2002): Effects of temperature and oxygen availability on greenhouse gas and nutrient dynamics in sediment of a eutrophic mid-boreal lake. - Biogeochemistry 59: 269-286.

[84] Livingstone, D.M. (2003): Impact of Secular climate change ont he thermal structure of a large temperate central european lake. - Climatic Change 57: 205-225. 
[85] Lofgren, B.M. (2002): Global warming influences on water levels, ice, and chemical and biological cycles in lakes: some examples. - In: McGinn NA (ed) Fisheries in a changing climate. American Fisheries Society, Bethesda, MD, pp. 15-22.

[86] Lotka, A.J. (1925): Elements of physical biology (Baltimore: Williams and Wilkins)

[87] MacLeod, J.C., Pessah, E. (1973): Temperature effects on mercury accumulation, toxicity, and metabolic rate in rainbow trout (Salmo gairdneri). - J. Fisher Res Board Can 30: 485-492.

[88] Magnuson, J.J. (2002.a): Future of adapting to climate change and variability. - In: McGinn NA (ed) Fisheries in a changing climate. American Fisheries Society, Bethesda, MD, pp. 283-287.

[89] Magnuson, J.J., Meissner, J.D., Hill, D.K. (1990): Potential changes in thermal habitat of great lakes fish after global climate warming. - Transactions American Fisheries Society 119: 254-264.

[90] Malmaeus, J.M. \& Håkanson, L. (2004): Development of a lake eutrophication model. Ecological Modelling 171: 35-63.

[91] Malmaeus, J.M., Blenckner, T., Markensten H., Persson, I. (2005): Lake phosphorus dynamics and climate warming: A mechanistic model approach. - Ecological Modelling 190: 1-14.

[92] Matulla, C., Schmutz, S., Melcher, A. Gerersdorfer, T., Haas, P. (2007): Assessing the impact of a downscaled climate change simulation on the fish fauna ina $\mathrm{n}$ Inner-Alpine River. - Int. J. Biometeorol. 52: 127-137.

[93] Matthews, W.J., Marsh-Matthews, E. (2003): Effects of drought on fish across axes of space, time and ecological complexity. - Freshwater Biol 48: 1232-1253.

[94] Medvinsky, A.B., Petrovskii, S.V., Tikhonov, D.A., Tikhonova, I.A., Ivanitsky, G.R., Venturino, E., Malchov, H. (2001): Biological factors underlying regularity and chaos in aquatic ecosystems: Simple models of complex dynamics. - J. Biosci. 26(1): 77-108.

[95] McKee, D., Atkinson, D. (2000): The influence of climate change scenarios on population of the mayfly Cloen dipterum. - Hydrobiologia 441: 55-62.

[96] McKee, D., Atkinson, D., Collings, S.E., Eaton, J.W., Harvey, I., Heyes, K., Hatton, D., Wilson, D., Moss, B. (2002): Macro-zooplankter responses to simulated climate warming in experimental freshwater microcosms. - Freshwater Biology. 47(8): 1557-1570.

[97] McKee, D., Atkinson, D., Collings, S.E., Eaton, J.W., Gill, A.B., Harvey, I., Hatton, K., Heyes, T., Wilson, D., Moss, B. (2003): Response of freshwater microcosm communities of nutrients, fish and elevated temperature during winter and summer. - Limnol. Oceanogr. 48: 707-722.

[98] Mehner, T., Dörner, H., Schultz, H. (1998): Factors determining the year-class strength of age-0 Eurasian perch (Perca fluviatilis, L.) in a biomanipulated reservoir. - Archiv of Fisheries and Marine Research 46: 241-251.

[99] Meise-Munns, C., Green, J., Ingham, M., Mountain, D. (1990): Interannual variability in the copepod populations of George Bank and the western Gulf of Maine. - Marine Ecology Progress Series 65: 225-232.

[100] Mimura, M., Murray, J.D. (1978): On a diffusive prey-predator model which exhibits patchiness. - J. Theor. Biol. 75: 249-262.

[101] Minns, C. K. (1992): Use of models for integrated assessment of ecosystem health. Journal of Aquatic Ecosystem Health 1: 109-118.

[102] Molinero, J.C., Annaville, O., Souissi, S., Balvay, G., Gerdeaux, D. (2007): Anthropogenic and climate forcing on the long-term changes of planktonic rotifers in Lake Geneva, Europe. - Journal of Plankton Research 2006 28(3): 287-296.

[103] Mooij, W.M. (1996): Variation in abundance and survival of fish larvae in shallow eutrophic lake Tjeukemeer. - Environmental Biology of Fishes 46: 265-279.

[104] Mooij, W.M., Hülsmann, S., De Senerpont Domis, L.N., Nolet, B.A., Bodelier, L.E., Boers, P.C.M., Dionisio Pires, M.L., Gons, H.J., Ibelings, B.W., Noordhuis, R., Portielje, 
R., Wolfstein, K., Lammens, R.R. (2005): The impact of climate change on lakes in the Netherlands: a review. - Aquatic Ecology 39: 381-400.

[105] Mooij, W.M., Van Nes, E.H. (1998): Statistical analysis of the somatic growth rate of 0+ fish in relation to temperature under natural conditions. - Canadian Journal of Fisheries and Aquatic Sciences 55: 451-458.

[106] Mooij, W.M., Janse, J.H., Domis, L.N., Hülsmann, S., Ibelings, B.W. (2007): Predicting the effect of climate change on temperate shallow lakes with the ecosystem model PCLake. - Hydrobiologia 584:443-454.

[107] Murty, A.S. (1986.a): Toxicity of pesticides to Fish. I. - CRC Press, Boca Raton, FL.

[108] Murty, A.S. (1986.b): Toxicity of pesticides to Fish. II. - CRC Press, Boca Raton, FL.

[109] Nouguier, J., Mostajir, B., Le Floc'h, E., Vidussi, F. (2007): An automatically operated system for simulating global change temperature and ultraviolet $\mathrm{B}$ radiation increases: application to the study of aquatic ecosystem responses in mesocosm experiments. Limnology and Oceanography 5: 269-279.

[110] Nussey, G., van Vuren, J.H.J., du Preez, H.H. (1996): Acute toxicity of copper on juvenile Mozambique tilapia, Oreochromis mossambicus (Cichlidae), at different temperatures. - S Afr J Wildlife Res 26: 47-55.

[111] Nyberg, P., Bergstrand, E., Degerman, E., Enderlein, O. (2001): Recruitment of pelagic fish in an unstable climate: studies in Sweden's four largest lakes. - AMBIO 30: 559-564.

[112] Omlin, M., Brun, R., Reichert, P. (2001): Biogeochemical model of Lake Zurich: sensitivity, identifiability and uncertainty analysis. - Ecol. Model. 141: 105-123.

[113] Odum, H.T. (1956): Primary production in flowing waters. - Limnol. Oceanogr. 1: 102117.

[114] O'Reilly, C.M., Alin, S.R., Plisnier, P.D., Cohen, A.S., McKee, B.A. (2003): Climate change decreases aquatic ecosystem productivity of Lake Tanganyika, Africa. - Nature 424: 766-768

[115] Peeters, F., Straile, D., Lorke, A., Ollinger, D. (2007): Turbulent mixing and phytoplankton spring bloom development in a deep lake. - Limnol. Oceanogr. 52(1): 286-298.

[116] Peperzak, L. (2003): Climate change and harmful algal blooms in the North Sea. - Acta Oecologica 24: 139-144.

[117] Poff, N.L., Brinson, M.M., Day, J.W. (2002): Aquatic ecosystem \& Climate change. Potential impacts on inland freshwater and coastal wetland ecosystems in the United States. - Pew Center on Global Climate Change. pp. 44.

[118] Pont, D., Hugueny, B., Beier, U., Goffaux, D., Melcher, A., Noble, R., Rogers, C., Roset, N., Schmutz, S. (2006): Assessing river biotic condition at a continental scale: a European approach using functional metrics and fish assemblages. - J. Appl. Ecol. 43: 70-80.

[119] Porter, J., Arzberger, P., Braun, H.-W., Bryant, P., Gage, S., Hansen, T., Hanson, P., Lin, C.-C., Lin, F.-P., Kratz, T., Michener, W., Shapiro, S., Williams, T. (2005): Wireless sensor networks for ecology. - Bioscience 55: 561-572.

[120] Puelles, M.L.F., Pinot, J.M., Valencia, J. (2003): Seasonal and interannual variability of zooplankton community in waters of Mallorca island (Baleric Sea, Western Mediterranean) 1994-1999. - Oceanologica Acta 26: 673-686.

[121] Quinlan, R., Douglas, M.S.V., Smol, J.P. (2005): Food web changes in arctic ecosystems related to climate warming. - Global Change Biology 11(8): 1381-1386.

[122] Rahel, F. (2002): Using current biogeographic limits to predict fish distributions following climate change. - In: McGinn N (ed) Fisheries in a changing climate. American Fisheries Society Symposium 32. American Fisheries Society, Bethesda, MD, pp 99-110

[123] Rahel, F.J., Keleher, C.J., Anderson, J.L. (1996): Potential habitat loss and population fragmentation for cold water fish in the North Platte River drainage of Rocky Mountain: response to climate warming. - Limnol. Oceanogr. 41: 1116-1123. 
[124] Reynolds, C.S. (1997): Vegetation processes in the pelagic: A model for ecosystem theory. - Ecology Institute.

[125] Riley, G.A. (1963): Theory of food-chain relations in the ocean; in The sea 2 (ed.) - M.N. Hill (London: Wiley) pp 436-463

[126] Rolinski, S., Horn, H., Petzoldt, T., Paul, L. (2007): Initifying cardinal dates in phytoplankton time series to enable the analysis of long-term trends. - Oecologia 153: 997-1008.

[127] Scheffer, M., Hosper, S.H., Meijer, M.L., Moss, B. (1993): Alternative equilibria in shallow lakes. - Trends in Ecology \& Evolution 8: 275-279.

[128] Scheffer, M., Straile, D., Van Nes, E.H., Hosper, H. (2001): Climatic warming causes regime shifts in lake food webs. - Limnology and Oceanography 46: 1780-1783.

[129] Schelske, C.L., Carrick, H. J., Aldridge, F.J. (1995): Can wind-induced resuspension of meroplankton affect phytoplankton dynamics? - Journal of the North American Benthological Society 14: 616-630.

[130] Schindler, D.W. (1997): Widespread effect on climatic warming on freshwater ecosystems in North America. - Hydrological Processes 11: 1043-1067.

[131] Schindler, D.W., Beaty, K.G., Fee, E. J., Cruikshank, D.R., DeBruyn, E.R., Findlay, D.L., Linsey, G.A., Shearer, A., Stainton, M.P., Turner, M.A. (1990): Effects on climatic warming on lakes of the central boreal forest. - Science 250: 967-970.

[132] Schmidt-Nielsen, K. (1990): Animal physiology: adaptation and environment, 4th edn. University of Cambridge Press, Cambridge, UK.

[133] Schmutz, S., Kaufmann, M., Vogel, B., Jungwirth, M. (2000): Grundlagen zur Bewertung der fischökologischen Funktionsfähigkeit von Fliessgewässern. - Bundesministerium für Land-und Forstwirtschaft, Umwelt und Wasserwirtschaft, Wasserwirtschaftskataster. http://publikationen.lebensministerium.at/

[134] Segel, L.A., Jackson, J.L. (1972): Dissipative structure: an explanation and an ecological example. - J. Theor. Biol. 37: 545-559.

[135] Sipkay, Cs., Hufnagel, L. (2007): Klímaváltozási szcenáriók összehasonlító elemzése balatoni makrogerinctelen együttes alapján - Hidrológiai Közlöny 87: 117-119.

[136] Sipkay, Cs., Nosek, J., Oertel, N., Vadadi-Fülöp, Cs., Hufnagel, L. (2007): Klímaváltozási szcenáriók elemzése egy dunai copepoda faj szezonális dinamikájának modellezése alapján. - "KLIMA-21" Füzetek 49: 80-90.

[137] Sipkay, Cs., Hufnagel, L. Révész, A., Petrányi, G. (2008.a): Seasonal dynamics of an aquatic macroinvertebrate assembly (Hydrobiological case study of Lake Balaton, №. 2) - Applied Ecology and Environmental Research 5(2): 63-78.

[138] Sipkay, Cs,. Horváth, L., Nosek, J., Oertel, N., Vadadi-Fülöp, Cs., Farkas, E., DrégelyKiss, Á., Hufnagel, L. (2008.b): Analysis of climate change scenarios based on modelling of the seasonal dynamics of a danubian copepod species. - Applied Ecology and Environmental Research 6(2)

[139] Sommer, U., Gliwitz, Z.M., Lampert, W., Duncan, A. (1986): The PEG-model of seasonal succession of planktonic events in fresh waters. - Archives in hydrobiology 106: 433-471.

[140] Steele, J.H. (ed.) (1977): Fisheries mathematics (London: Academic)

[141] Stefan, H.G., Fang, X., Eaton, J.G. (2001): Simulated fish habitat changes in North American lakes in response to projected climate warming. - Trans. Am. Fisheries Soc. 130: 459-477.

[142] Straile, D. (2002): Die saisonale Entwicklung des Kohlenstoffkleislaufes im pelagischen Nahrungsnetz des Bodensees - Eine Analyse von massenbilanzierten Flußdiagrammen mit Hilfe der Netzwerktheorie. PhD Thesis - University of Konstanz. Hartung-Gorre Verlag, Konstanz.

[143] Straile, D. (2005): Food webs in lakes - seasonal dynamics and the impacts of climate variability. - In: Belgrano, A., Scharler, U.M., Dunne, J. \& Ulanowicz, R.E. 
[144] Straile, D., Livingstone, D.M., Weyhenmeyer, G.A., George, D.G. (2003): Complex effects of winter warming ont he physico-chemical characteristic of a deep lake. Limnology and Oceanography 48: 1432-1438.

[145] Thackeray, S.J., Jones, I.D., Maberly, S.C. (2008): Long-term change in the phenology of spring phytoplankton: species-specific responses to nutrient enrichment and climatic change. - Journal of Ecology 96: 523-535.

[146] Thienemann, A. (1925): Die Binnengewässer Mitteleuropas. Eine limnologische Einführung. - Schweitzerbart'sche, Stuttgart.

[147] Tilzer, M.M., Bossard, P. (1992): Large lakes and their sustainable development. Aquatic Sciences 54: 91-103.

[148] Vadadi-Fülöp, Cs., Sipkay, Cs., Hufnagel, L. (2007): Klímaváltozási szcenáriók értékelése egy szitakötőfaj (Ischnura pumilio, Charpentier, 1825) szezonális dinamikája alapján - Acta Biologica Debrecina, Oecol. Hung. 16: 211-219.

[149] Vadadi-Fülöp, Cs., Hufnagel, L., Sipkay, Cs., Verasztó, Cs. (2008): Evaluation of climate change scenarios based on aquatic food web modelling - Applied Ecology and Environmental Research 6(1): 1-28.

[150] Verburg, P., Hecky, R.E., Kling, H. (2003): Ecological consequences of a century of warming in Lake Tanganyika. - Science 301: 505-507.

[151] Viitasalo, M., Vuorinen, I., Ranta, E. (1990): Changes in crustacean mesozooplankton and some environmental parameters in the Archipelago Sea (Northern Baltic) in 19761984. - Ophelia 31: 207-217.

[152] Vinogradov, M.E., Menshutkin, V.V. (1977): The modeling of open sea ecosystems; in The sea. Ideas and observations on progress in the study of the sea 6 (ed.) - E.D. Goldberg (New York: John Wiley)

[153] Volterra, V. (1926): Variations and fluctuations of the numbers of individuals in animal species living together. - J. Cons. Perm. Int. Ent. Mer. 3: 3-51.

[154] Vörös, L., Kiss, N. (1985): A fitoplankton szezonális periodicitása és annak összefüggése az eutrofizálódással. Irodalmi áttekintés és balatoni esettanulmány. - In: Fekete, G. (szerk) A cönológiai szukcesszió kérdései. Akadémiai Kiadó, Budapest.

[155] Vinebrooke, R.D., Leavitt, P.R. (1999): Phytobenthos and Phytoplankton as Potential Indicators of Climate Change in Mountain Lakes and Ponds: A HPLC-Based Pigment Approach, by Rolf D. Vinebrooke and Peter R. - Journal of the North American Benthological Society 18: 15-33.

[156] Wagner, A., Benndorf, J. (2007): Climate-driven warming during spring destabilises a Daphnia population: a mechanistic food-web approach. - Oecologia 151:351-367

[157] Weyhenmeyer, G.A., Blenckner, T., Pettersson, K. (1999): Changes on the plankton spring outburst related to the North Atlantic Oscillation. - Limnology Oceanography 44: 1788-1792.

[158] Wiedner, C., Rücker, J., Brüggemann, R., Nixdorf, B. (2007): Climate change affects timing and size of populations of an invasive cyanobacterium in temperate regions. Oecologia 152: 473-484.

[159] Williamson, P., Gribbin, J. (1991): How plankton change the climate. - New Sci. 16: 4852.

[160] Winder, M., Schindler, D.E. (2004): Climatic effects on phenology of lake processes. Global Change Biology 10: 1844-1856.

[161] Wood, R.J., Boesch, D.F., Kennedy, V.S. (2002): Future consequences of climate change for the Chesapeake Bay ecosystem and its fisheries. - In: McGinn, N.A. (ed): Fisheries in a changing climate. American Fisheries Society, Bethesda, MD, pp. 171-184. 